\title{
Buckling Analysis of Circular Shells for RDE Reactor Pressure Vessel by Finite Element Study and Analytical Model
}

\author{
Sri Sudadiyo ${ }^{\star 1}$, Muhammad Subekti ${ }^{1}$
}

${ }^{1}$ Center for Nuclear Reactor Technology and Safety, National Nuclear Energy Agency of Indonesia (BATAN), Gd.80 Tangerang Selatan, Indonesia, 15310

\begin{tabular}{l}
\hline ARTICLE INFORMATION \\
\hline Article History: \\
Received: \\
11 October 2019 \\
Received in revised form: \\
06 December 2019 \\
Approved: \\
09 December 2019 \\
\hline
\end{tabular}

\section{Keywords:}

Buckling

Circular shells

Reactor pressure vessel RDE

\begin{abstract}
BUCKLING ANALYSIS OF CIRCULAR SHELLS FOR RDE REACTOR PRESSURE VESSEL BY FINITE ELEMENT STUDY AND ANALYTICAL MODEL.One of the basic design considerations for circular shells of Reactor Pressure Vessel (RPV) components of Reaktor Daya Eksperimental (RDE) is buckling mode shape of geometric structure imperfections. Geometric structure is prone to a large number of imperfections due to the manufacturing difficulties. Moreover, determination of critical loads of circular shell structure can be properly approximated only through randomness in the geometry. As at the basic design phase this is possible and expensive to measure the geometric structure imperfections in situ or in laboratory, a simulation of computer code should be provided. In this paper, a contribution is made to numerical simulation by finite element study and analytical model by Monte Carlo technique approach of such circular shells for RPV components. For this reason, computer code SolidWorks is used in the implementation finite element analysis and Fortran code is developed for analytical model analysis. The main objective of this investigation is to provide a comprehensive analysis of unstable structure due to the buckled geometric imperfection in the design calculations involved. A method of solution attempts to use the linearized equilibrium equations to interpret geometric imperfections as structure of circular shells associated with the RPV components of RDE. A number of calculation results carried out on a computer code are presented to illustrate the design of RPV components that are safe from the buckled shape failure. It is found that both of the computer code results are very similar with greatest difference value of vibrational amplitude of $0.00699 \%$ and smallest value for buckling load factor of 12.51 on upper circular shell under 750 ${ }^{\circ} \mathrm{C}$ conditions.
\end{abstract}

\begin{abstract}
ABSTRAK
ANALISIS TEKUK SEL SILINDER UNTUK BEJANA TEKAN REAKTOR RDE DENGAN STUDI ELEMEN HINGGA DAN MODEL ANALITIS.Salah satu pertimbangan desain dasar untuk sel silinder komponen Reactor Pressure Vessel (RPV) dari Reaktor Daya Eksperimental (RDE) adalah bentuk mode tekuk ketidaksempurnaan struktur geometri. Struktur geometris rentan terhadap sejumlah besar ketidaksempurnaan akibat kesulitan dalam manufaktur. Selain itu, penentuan beban kritis struktur sel silinder hanya dapat didekati dengan tepat melalui keacakan dalam geometri. Karena pada fase desain dasar ini adalah mungkin dan mahal untuk mengukur ketidaksempurnaan struktur geometris di bengkel kerja atau di laboratorium, simulasi kode komputer harus disediakan. Dalam tulisan ini, kontribusi dibuat untuk simulasi numerik dengan studi elemen hingga dan model analitis dengan pendekatan teknik Monte Carlo dari sel-sel melingkar untuk komponen RPV. Untuk alasan ini, kode komputer SolidWorks digunakan dalam pelaksanaan analisis elemen hingga dan kode Fortran dikembangkan untuk analisis model analitis. Tujuan utama dari penelitian ini adalah untuk memberikan analisis yang komprehensif dari struktur yang tidak stabil akibat ketidaksempurnaan geometrik tekuk dalam perhitungan desain yang terlibat. Metode penyelesaiandengan menggunakan persamaan kesetimbangan linierisasi untuk menginterpretasikan ketidaksempurnaan geometris sebagai struktur sel silinder yang terkait dengan komponen RPV dari RDE. Hasil perhitungan yang dilakukan dengan kode komputer disajikan untuk menggambarkan desain komponen RPV yang aman dari kegagalan bentuk tekuk. Diperoleh bahwa kedua hasil kode komputer sangat mirip dengan perbedaan nilai amplitudo getaran terbesar $0,00699 \%$ dan nilai terkecil untuk faktor beban tekuk 12,51 pada sel silinder atas pada kondisi $750^{\circ} \mathrm{C}$.

Kata Kunci: buckling, circular shells, reactor pressure vessel, RDE
\end{abstract}

C 2019 Jurnal Pengembangan Energi Nuklir. All rights reserved

\section{INTRODUCTION}

The reactor pressure vessel (RPV) of Reaktor Daya Eksperimental (RDE) is basically

designed with substantial care to ensure safe operation when used within the prescribed

${ }^{*}$ Corresponding author.

E-mail: sudadiyo@batan.go.id 
temperature and pressure limits [1-4]. The circular shells of RPV is in generally highly efficient structure. This cylindrical structure is prone to a large number of imperfections due to the manufacturing difficulties. The preference of RPV must have the capability, internal pressure rating, corrosion resistance and design features suitable for intended use [5]. When the RPV cannot function to maintain the helium gas that occupies the gap between the core barrel and the inner shell wall, this phenomenon does not cause fuel heat to rise inside the core and this cannot ultimately meltdown the reactor core, unlike in the case study of nuclear accident in Japan when the pressure vessel is malfunction, heat continues to accumulate in the reactor and then the core meltdown and damaged [6-8]. Other than that, neutron irradiation embrittlement reduces the fracture toughness of RPV materials during plant operation [9-11]. Considering such situations above, a potential for accident can be avoided by developing a safety consideration of the RPV wall design.

In earliest investigation into the basic design of RDE, RPV was configured to operate safely under a specific pressure 30 bars and output temperature $700{ }^{\circ} \mathrm{C}$ [1-4]. In reference 1 , the RPV configuration refers to the American Society of Mechanical Engineers (ASME) codes and standards Section III, about construction rulers for boilers and pressure vessels of nuclear facility components [1]. Circular shells of the RPV components will be manufactured by welding rolled carbon steel plates. Due to manufacturing variations, fabricated shell differs from perfect shape and there can be variations in shell wall thickness and material properties. Effect of imperfections in the geometry shape of shell wall thickness will influence buckling load of RPV. When imperfections in circular shells come into circumstance strength of shells will decrease. Dai, et al. studied on the hollow structure bending of cylindrical shell with functionally graded materials [12]. They concluded that geometric shape influences the dynamic behaviour of the outer circular shell. Mao, et al. investigated on the structural integrity of reactor pressure vessel within a prescribed period of time. They found that geometric imperfections accelerate the damage evolution on thinnest site [13].
Buckling is an unstable structure under critical pressure load less than the applied load [14]. Buckling of circular shells will occur when a RPV structure of RDE is predicted by encountering the combination actions of axial compressive strength, internal pressure, and operating temperature. The determination of buckling load factor(BLF) as a safety factor for geometric structure of a RPV which is experimentally safe, is a time-consuming problem which arises frequently in nuclear power plant. Unfortunately exact analytical solutions to BLF exist for simple models of geometric structure and uncomplicated loading conditions. Therefore, the finite element model is used to determine the buckling load factor of circular shells of a RPV for RDE. The Monte Carlo approach will be used to check the validity of the BLF value generated from the finite element model. This study aims to provide a comprehensive analysis of unstable structure in the design calculations involved. The solution method does the following (a). Euler's formula involves only one elastic constant, (b). the geometric imperfections shape of the circular shell buckling are predicted by using the linearized equations, (c). the critical load conditions are expressed numerically made it possible to estimate the efficient structure, (d) vibrational amplitude of buckling is predicted, and(e). the BLF value of $\mathrm{RPV}$ is obtained.

\section{BASIC EQUATIONS}

Rigid geometric structure of circular shells is very important for the RPV components of RDE. This is very often subjected to compressive strength so that rigid structure has to be designed against the buckling load of RPV. Figure 1 shows the configuration that has been done for RPV components of RDE [4]. It considered a circular shell, of height $Z$, radius $R$, and wall thickness $H$, subject to an internal pressure $P_{i n}$. The various dimensions of the RPV structure are shown in Fig. 1and technical specifications in Table 1[1]. In the present paper, the linearized equilibrium expressions are often used for buckling analysis.

- According to Euler's formula, the axial stress resulting from pressurization is represented by the following equation : 


$$
\sigma_{a x}=\frac{R\left(P_{i n}-P_{e x t}\right)}{2 H}
$$

where $P_{\text {in }}($ in $\mathrm{Pa})$ and $P_{\text {ext }}($ in $\mathrm{Pa})$ are uniform internal pressure of helium gas and uniform ext ernal pressure of circular shells, respectively.

- As well, according to Euler's formula, critical compressive stress is represented by equation :

$$
\sigma_{c r}=\frac{C \pi^{2} E I}{Z^{2} A}
$$

where $C$ is the end condition constant value in the form of twist angle $\left(\cong \cos 90^{\circ}\right.$ for axisymmetric mode in the present study), $I$ is moment of inertia (in $\mathrm{m}^{4}$ ), $Z$ is height of circular shell (in $\mathrm{m}$ ), and $A$ is cross-section area (in $\mathrm{m}^{2}$ ).

- Associated values of vibrational amplitude (dimensionless) for buckling parameter is usually written in the form [15] :

$$
\lambda=\left[3\left(1-\mu^{2}\right)\right]^{1 / 2}\left(\frac{R}{E H}\right)\left[\sigma_{c r}-\sigma_{a x}\right]
$$

where $\mu$ is Poisson's ratio (dimensionless), $E$ is elastic material modulus or Young's modulus (in $\mathrm{Pa}), \sigma_{c r}$ is critical compressive stress (in $\mathrm{Pa}$ ), $R$ is the minimum radius of gyration (in $\mathrm{m}$ ), and $H$ is wall thickness of the circular shell (in m).

- Non-dimensional buckling load factor of geometric imperfections is determined by :

$$
B L F=\frac{F_{c r}}{F_{a p}}
$$

where $F_{c r}\left(\right.$ in N) and $F_{a p}($ in N) are critical buckling load of a circular shell with imperfections and the applied compressive load of a perfect circular shell, respectively.

Table 1. Technical specifications of design data for RPV [1]

\begin{tabular}{lc}
\hline \multicolumn{1}{c}{ Property, Unit } & Value \\
\hline Upper circular shell wall thickness, mm & 60 \\
Inner diameter of upper circular shell, mm & 4200 \\
Height of upper circular shell, mm & 2929 \\
Lower circular shell wall thickness, mm & 100 \\
Inner diameter of lower circular shell, mm & 4200 \\
Height of lower circular shell, mm & 3394 \\
Height of RPV, mm & 11680 \\
Young's modulus of carbon steel SA516-70, & 200 \\
GPa & \\
Poisson's ratio & 0.29 \\
\hline
\end{tabular}

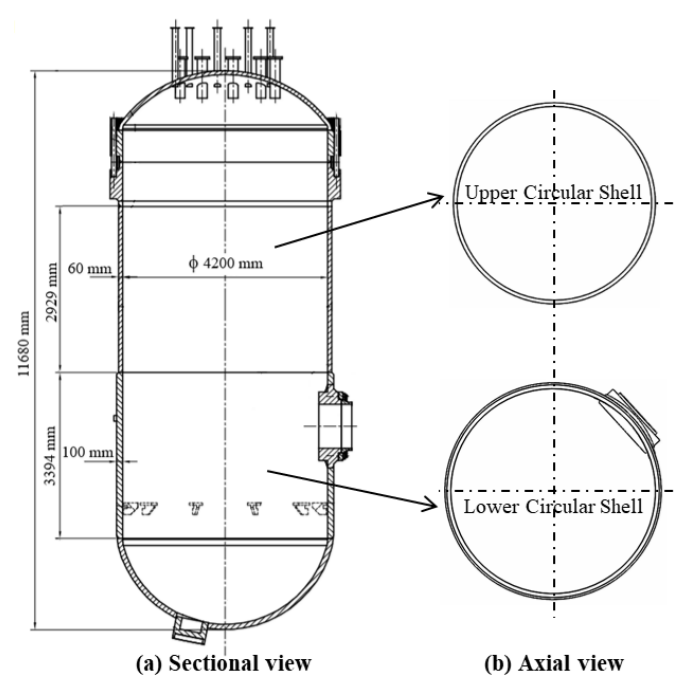

Figure 1. Configuration of reactor pressure vessel for RDE [4].

\section{METHODOLOGY}

This section lays out the methodology for simulation of circular shells similar to the RPV components of RDE. Geometric model and dimensions of RPV components for RDE including upper circular shell and lower circular shell have been performed by using the inhouse computer code $R P V \_R D E$.exe [1], which allows for finite element model buckling analysis from computer code SolidWorks. Figure 2 shows simulation steps for finite element study by SolidWorks. Then the Monte Carlo technique is used to calculate the values of vibrational amplitude and buckling load factor for the analytical model by using Eqs. (1) to (4). Centroid relative to coordinate system of wall thickness is generated by Monte Carlo technique which requires the use of random number generator. Random number generator applied for simulating thickness of circular shell generates the numbers that follow uniform distribution. Generated circular shells are than compared with the finite element method for simulating thickness of circular shell to check the significance values of wall thickness. Therefore it is necessary to develop a Fortran code for calculating vibrational amplitude $(\lambda)$ and buckling load factor (BLF) for axial loads. Figure 3 shows calculation procedure of the code for Monte Carlo technique approach. Table 2 describes design thermodynamic parameter of RPV components for RDE that refers to HTR-10 plant [1, 3]. 


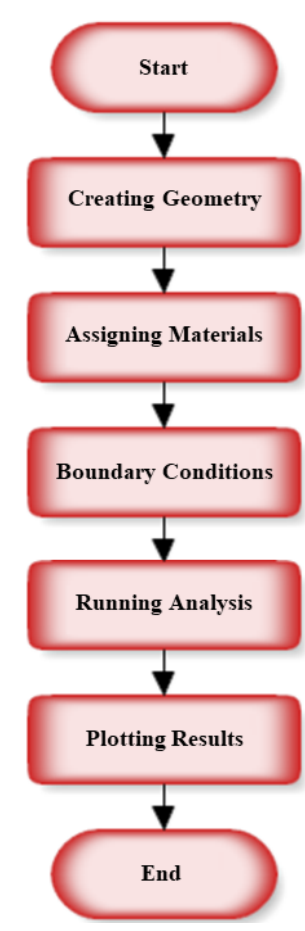

Figure 2. Simulation procedure for circular shells by finite element analysis.

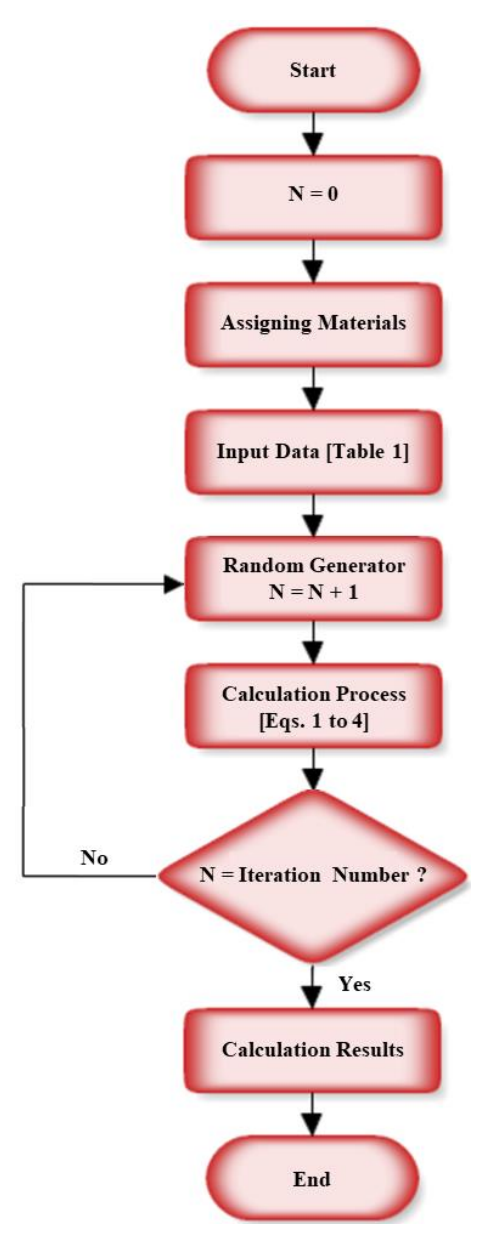

Figure 3. Calculation code procedure for circular shells by Monte Carlo technique approach.
Table 2. Operation data for RPV of RDE [1,3]

\begin{tabular}{lcc}
\hline \multicolumn{1}{c}{ Given Parameters, Unit } & $\begin{array}{c}\text { HTR- } \\
10\end{array}$ & RDE \\
\hline $\begin{array}{l}\text { Reactor thermal power, } \mathrm{MW}_{\text {th }} \\
\text { Internal pressure(helium pressure), }\end{array}$ & 3 & 3 \\
$\mathrm{MPa}$ & & \\
External pressure (air pressure), $\mathrm{MPa}$ & 0.05 & 0.05 \\
Outlet temperature, ${ }^{\circ} \mathrm{C}$ & 700 & 700 \\
Inlet temperature, ${ }^{\circ} \mathrm{C}$ & 250 & 250 \\
Helium mass flow rate, $\mathrm{kg} / \mathrm{s}$ & 4.27 & 4.4 \\
\hline
\end{tabular}

\section{RESULTS AND DISCUSSION}

The buckling analysis of circular shell for $\mathrm{RDE}$ reactor pressure vessel has been done by computer code SolidWorks. It has observed that the results for critical buckling are good matched with the computing statistical results with Monte Carlo simulation technique approach. In this section, the parametric study is conducted to demonstrate the effects of temperature, resultant vibrational amplitude, and geometric dimensions on the fundamental buckling mode shape of circular shells for RPV components of RDE. For a clear manifestation, calculation results are presented on tables and contour images. It is well known that the relationship of vibrational amplitude and stresses is a linearized equation, as in Eq. (3), so that it is proven that the increment in operating temperature leads to an alleviation of the vibrational amplitude due to a reduction in the flexural rigidity of the circular shells. The axial compressive load is induced by temperature rise.

Buckling has become a dominance of failure mechanism when compressive stresses generated by the internal and external pressures, dead weights, and operating temperature for circular shells (including upper shell and lower shell) of RPV components. Figure 4 describes the mesh generation of finite element model analysis by using computer code SolidWorks for upper circular shell and lower circular shell. Table 3 explains the calculation results of stress and load values for upper circular shell and lower circular shell under critical condition in axial direction. These values are used to calculate the vibrational amplitude ( $\lambda$ values) and nondimensional buckling load factor (BLF values) 
of geometric imperfections in Monte Carlo technique approach. In general, applied force loads are related to dead weights of an ellipsoidal head, flanges, and upper shell which are definite in analysis. Therefore, stresses due to the applied loads are constant calculations for analytical model.

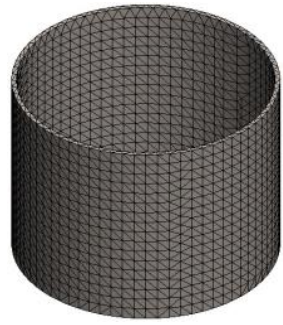

(a) Upper circular shell

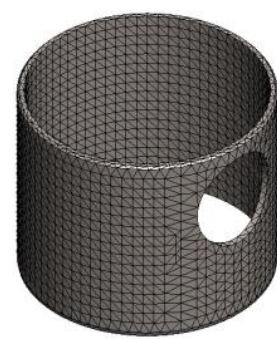

(b) Lower circular shell
Figure 4. Finite element model by computer code SolidWorks for circular shells of RPV.

Table 3. Stressesand loads values of circular shells under critical condition for analytical model

\begin{tabular}{|c|c|c|c|c|}
\hline \multirow{2}{*}{ Parameter } & \multicolumn{2}{|c|}{$\begin{array}{l}\text { Upper Circular } \\
\text { Shell }\end{array}$} & \multicolumn{2}{|c|}{$\begin{array}{c}\text { Lower Circular } \\
\text { Shell }\end{array}$} \\
\hline & $400^{\circ} \mathrm{C}$ & $750^{\circ} \mathrm{C}$ & $400^{\circ} \mathrm{C}$ & $750^{\circ} \mathrm{C}$ \\
\hline \multirow{2}{*}{$\begin{array}{l}\text { Axial stress (in } \\
\text { Pa) by Eq. (1) }\end{array}$} & & & 0 & \\
\hline & 7 & & & \\
\hline \multirow{2}{*}{$\begin{array}{l}\text { Compressive } \\
\text { stress (in Pa) by } \\
\text { Eq. (2) }\end{array}$} & 3.9589 & & 2.8016 & \\
\hline & $E+007$ & $\mathrm{E}+$ & $E+007$ & $\mathrm{E}+007$ \\
\hline \multirow{2}{*}{$\begin{array}{l}\text { Buckling load (in } \\
\text { N) for Eq. (4) }\end{array}$} & 2.10 & & 3.2333 & 1.9468 \\
\hline & $\mathrm{E}+0$ & $E+007$ & $E+007$ & $E+007$ \\
\hline $\begin{array}{l}\text { Applied load (in N) } \\
\text { for Eq. (4) }\end{array}$ & 974606 & 974606 & 1502977 & 1502977 \\
\hline
\end{tabular}

In general, buckling analysis of circular shells for RPV components requires $\lambda$ values (the vibrational amplitude) to obtain estimates of the buckling mode shape. Table 4 reveals the values of vibrational amplitude calculation for circular shells of RPV components under 400 ${ }^{\circ} \mathrm{C}$ and $750{ }^{\circ} \mathrm{C}$. It can be seen that the $\lambda$ absolute values are very similar or in good agreement between finite element study and analytical model by using Monte Carlo technique approach. The difference values of vibrational amplitude are $0.00234 \%$ and $0.00699 \%$ under temperatures of $400{ }^{\circ} \mathrm{C}$ and $750{ }^{\circ} \mathrm{C}$ for upper circular shell. This can be explained as follows. In the present studies (finite element method and analytical model) a linear stability analysis is carried out for circular shells including upper circular shell and lower circular shell, as shown in Fig. 1, under axial loads. This linear analysis assumes a perfect geometric system and predicts the vibrational amplitude of buckling parameter for the geometrical imperfection implementation. In the linear analysis it is assumed that the wall thickness of circular shells is constant. Nevertheless, this linear analysis still provides useful results of the buckling behavior. At finite element method by SolidWorks the geometry and material properties are determined along with boundary and load conditions for vibrational amplitude. Subsequently, a convergence analysis will be conducted in order to determine element type and mesh size. Whereas at analytical model study by using Monte Carlo approach the random coordinate fields into the geometry and material properties are generated to predict the vibrational amplitude (as in Eq.(3)).

Table 5 lists the results of buckling load factor calculation for upper circular shell and lower circular shell of RPV components. All BLF values show greater than 1 . This means buckling is not predicted because the applied load indicates a value smaller than the estimated critical load so that buckling is not expected or on the other hand, the RPV component design is safe from the buckled shape failure.

Table $4 . \lambda$ values for RPV components of RDE

\begin{tabular}{ccccc}
\hline \multirow{2}{*}{ By } & \multicolumn{2}{c}{$\begin{array}{c}\text { Upper Circular } \\
\text { Shell }\end{array}$} & \multicolumn{2}{c}{$\begin{array}{c}\text { Lower Circular } \\
\text { Shell }\end{array}$} \\
\cline { 2 - 5 } & $400^{\circ} \mathrm{C}$ & $750^{\circ} \mathrm{C}$ & $400^{\circ} \mathrm{C}$ & $750^{\circ} \mathrm{C}$ \\
\hline Finite element & 4.2656 & 2.8614 & 1.5952 & 1.1264 \\
study & $\mathrm{E}-005$ & $\mathrm{E}-005$ & $\mathrm{E}-004$ & $\mathrm{E}-004$ \\
Analytical model by & 4.2655 & 2.8612 & 1.5952 & 1.1264 \\
Eq. (3) & $\mathrm{E}-005$ & $\mathrm{E}-005$ & $\mathrm{E}-004$ & $\mathrm{E}-004$ \\
\hline
\end{tabular}

Table 5. Buckling load factor for RPV components of RDE

\begin{tabular}{ccccc}
\hline \multirow{2}{*}{ By } & \multicolumn{2}{c}{$\begin{array}{c}\text { Upper Circular } \\
\text { Shell }\end{array}$} & \multicolumn{2}{c}{$\begin{array}{c}\text { Lower Circular } \\
\text { Shell }\end{array}$} \\
\cline { 2 - 5 } & $400^{\circ} \mathrm{C}$ & $750^{\circ} \mathrm{C}$ & $400^{\circ} \mathrm{C}$ & $750^{\circ} \mathrm{C}$ \\
\hline $\begin{array}{c}\text { Finite element } \\
\text { study }\end{array}$ & 21.624 & 12.615 & 21.513 & 12.96 \\
$\begin{array}{c}\text { Analytical model by } \\
\text { Eq. (4) }\end{array}$ & 21.580 & 12.521 & 21.512 & 12.95 \\
\hline
\end{tabular}


Figures 5 and 6 illustrate the typical plot of buckling mode shape mechanism results by using finite element analysis for upper and lower circular shells of RPV, respectively. The vibrational amplitude and the dimensions in axial and in circumferential directions of the two localized geometric imperfections represented are both not arbitrarily and independently varied. That is, due to buckling mode shape the amplitude of the first local nozzle hole is interdependent on specified circular shell radius and the picked wall thickness.

Temperature condition of $750{ }^{\circ} \mathrm{C}$, axial stress is greater than the critical stress so the animation predicts the negative values of vibration amplitude inward for lower circular shell, as seen in Fig. 6 (b). This investigation was limited on the isotropic shell material with different elastic material modulus at elevated temperature $\left(750{ }^{\circ} \mathrm{C}\right.$ ) and a Poisson's ratio equal to 0.29 [1]. Hence, for the investigation results of the influences of a nozzle hole on the damaging effect of the lower circular shell dimensions in isotropic materials visible in Fig. 6.
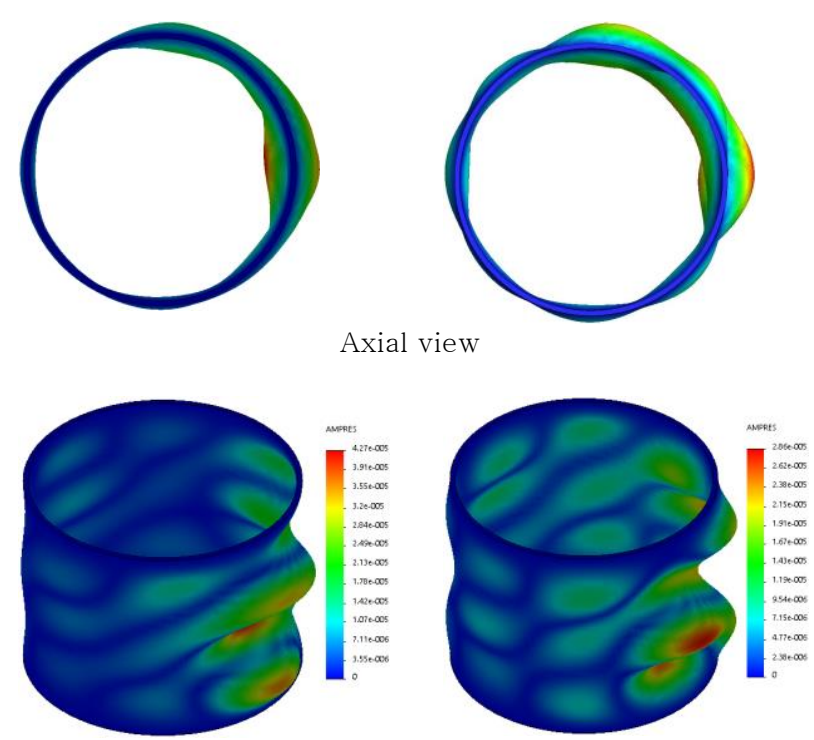

Side view

(a) Temperature $400^{\circ} \mathrm{C}$

(b) Temperature $750^{\circ} \mathrm{C}$

Figure 5. Animation prediction of buckling mode shape for upper circular shell of RPV.
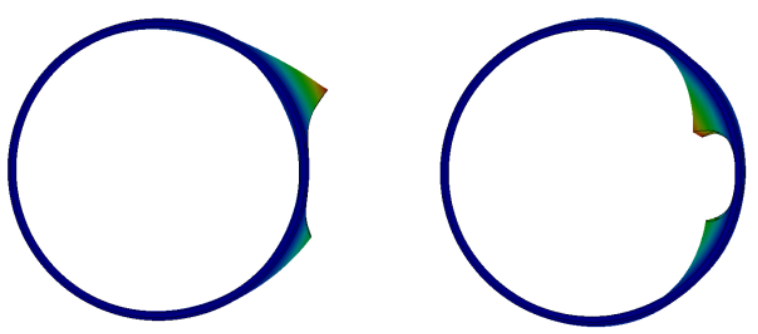

Axial view

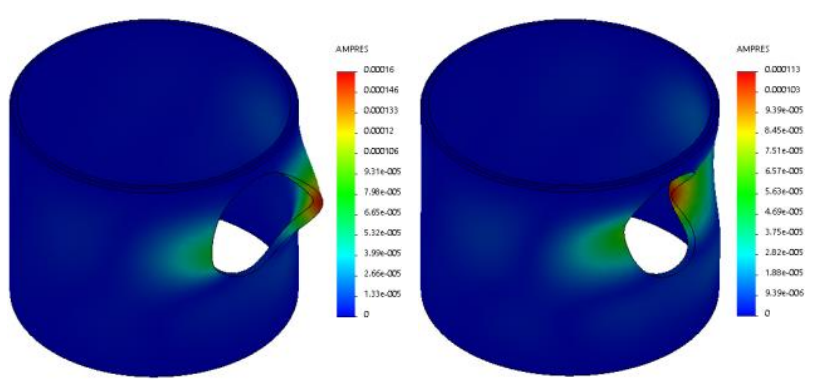

Side view

$\begin{array}{ll}\text { (a) Temperature } 400{ }^{\circ} \mathrm{C} & \text { (b) Temperature } 750{ }^{\circ} \mathrm{C}\end{array}$

Figure 6. Animation prediction of buckling mode shape for lower circular shell of RPV.

In the steady state condition, calculations were performed for upper circular shell and lower circular shell. At Figures 7 and 8 the linearized buckling analysis results of geometric imperfections with finite element study by SolidWorks simulation and with analytical model by Monte Carlo technique approach, in both cases subject to combined axial load of pressurization and applied load of dead weight, are plotted. For combined loads, the load ratio is maintained through a gradually calculations. Figures 7 and 8 disclose the almost coincidence of the SolidWorks simulation results for upper circular shell less than lower circular shell respectively. This confirms the assumption that lower circular shell which are sensitive to geometric imperfections due to the nozzle hole under axial compressive stress are extremely sensitive to combined loads. Meanwhile, in the upper circular shell precisely in the construction above the nozzle hole will also be sensitive to combined loads. In this case, critical buckling load is only $1.2203 \mathrm{E}+007 \mathrm{~N}$, identical to results achieved by linear analysis for analytical model of upper circular shell under temperature of $750{ }^{\circ} \mathrm{C}$ 

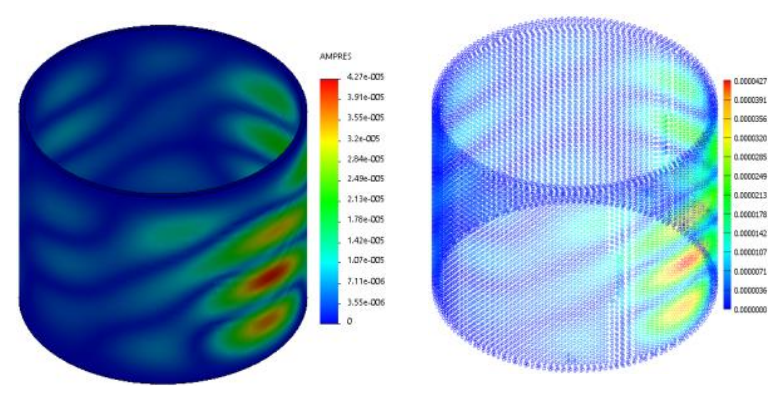

Upper circular shell
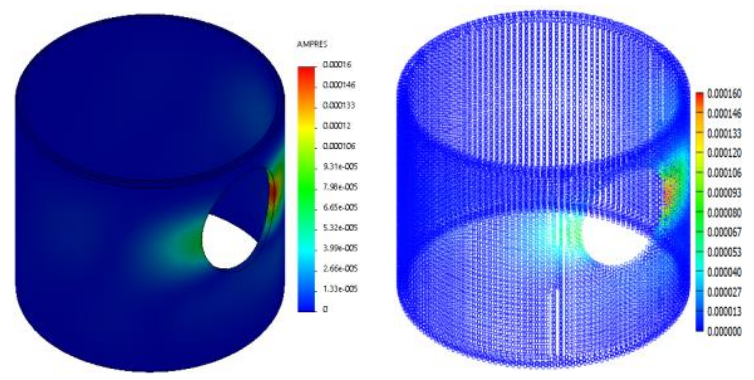

Lower circular shell

(a) SolidWorks simulation

(b) Monte Carlo approach

Figure 7. Contour plot of vibrational amplitude on upper circular shell under temperature $400^{\circ} \mathrm{C}$.
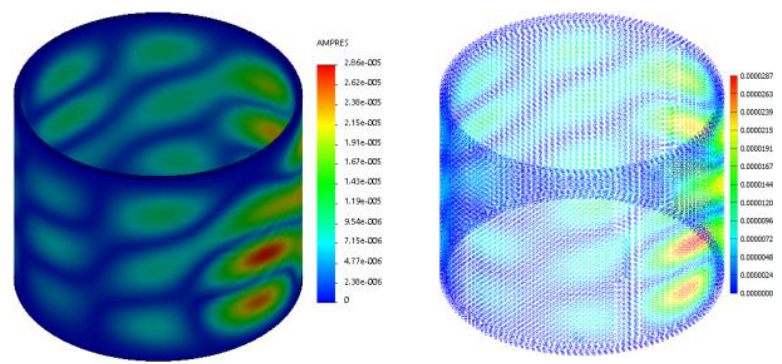

Upper circular shell
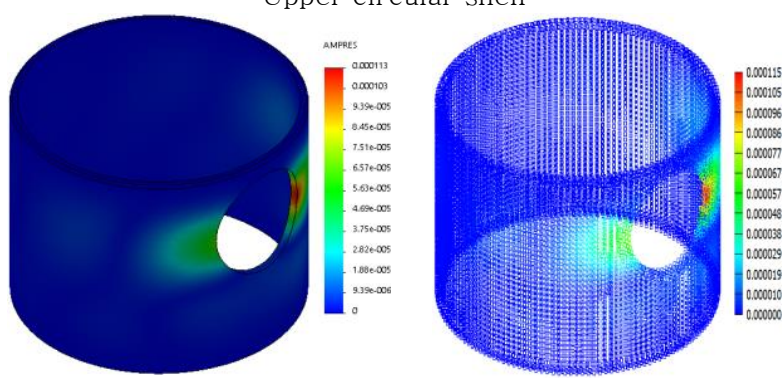

Lower circular shell

(a) SolidWorks simulation

(b) Monte Carlo approach

Figure 8. Contour plot of vibrational amplitude on lower circular shell under temperature $750{ }^{\circ} \mathrm{C}$.

Verification of the present paper, comparisons made with $\lambda$ values in Table 4 and BLF values in Table 5 for upper circular shell and lower circular shell under temperatures of $400{ }^{\circ} \mathrm{C}$ and $750{ }^{\circ} \mathrm{C}$. The comparisons indicate a maximum discrepancy of vibrational amplitude and buckling load factor less than $0.007 \%$ and $0.75 \%$, respectively. In addition, the results of buckling mode analysis show excellent agreement between finite element study and analytical model (by Monte Carlo technique approach) as seen in Table 3, Table 4, Fig. 7, and Fig. 8. In this paper, it is remarkable that an increase in $\lambda$ values is not a consequence of rising twist angle. However, a very dangerous interaction between local buckling and column buckling can occur because of the second order pattern effect of axial compressive stress. Bending effects can also cause loss of stiffness due to shell ovalization. Thus, the contributions of axial stress resulting from pressurization and applied loads to buckling parameter of geometric imperfections are very dominance towards the safety factor or buckling load factor of RPV components for RDE.

\section{CONCLUSION}

The buckling analysis for upper circular shell and lower circular shell has been pursued in buckling load factor exploiting the linearized equilibrium equations to describe the vibrational amplitude ( $\lambda$ values). It has been shown that the numerical results obtained by computer codes SolidWorks and analytical model of Monte Carlo approach coincide perfectly with each other. In the cases of RPV components for RDE, the numerical analysis of geometric imperfections has been carried out both for upper circular shell and for lower circular shell of $\lambda$ values, namely 4.2656 E-005 and $1.5952 \mathrm{E}-004$ of temperature $400{ }^{\circ} \mathrm{C}$, respectively. A smallest value of BLF is obtained circa 12.615 for upper circular shell under temperature of $750^{\circ} \mathrm{C}$. The maximum discrepancy of $\lambda$ values is less than $0.007 \%$, and buckling load factor is $0.75 \%$ between finite element study and analytical model.

\section{ACKNOWLEDGMENT}

The author wish to acknowledge support from Kementerian Riset, Teknologi dan Pendidikan Tinggi (Kemenristekdikti) for research grant of Insinas-Flagship RDE 2018 to 2019. The present work is also budgeted by the 
Center for Nuclear Reactor Technology and Safety, BATAN.

\section{REFERENCES}

[1]. S. Sudadiyo, T. Taryo, T. Setiapura, A. Nugroho, Krismawan. "Preliminary Design of Reactor Pressure Vessel for RDE". International Journal of Mechanical Engineering and Technology, Volume (9), Number (6), 2018, pp. 889-898.

[2]. M. Pancoko, A. Nugroho, D. Priambodo, T. Setiapura. "Design Study of a Straight Tube Bundle Steam Generator for Reaktor Daya Eksperimental”. International Journal of Mechanical Engineering and Technology, Volume (9), Number (65), 2018, pp. 531-540.

[3]. S. Sudadiyo. "Preliminary Design of RDE Feedwater Pump Impeller". Tri Dasa Mega, Volume (20), Number (1), 2018, pp. 1-12.

[4]. S. Sudadiyo, T. Taryo, Rokhmadi, E. Saragi. "Design development and safety analysis on reactor pressure vessel structure of RDE (in Bahasa Indonesia)". BATAN, Tangerang Selatan, Final Report of Insinas-Flagship for RDE, 2018

[5]. Y.M. Shabana, A. Elsawaf, H. Khalaf, Y. Khalil. "Stresses Minimation in Functionally Graded Cylinders Using Particle Swarm Optimization Technique". International Journal of Pressure Vessel and Piping, Volume (154), 2017, pp.1-10.

[6]. J.F. Mao, J.W. Zhu, S.Y. Bao, L.J. Luo, Z.L. Gao. "Creep Deformation and Damage Behavior of Reactor Pressure Vessel under Core Meltdown Scenario". International Journal of Pressure Vessel and Piping, Volume (139-140), 2016, pp.107-116.

[7]. J. Cho, J.H. Park, D.S. Kim, H.G. Lim. "Quantification of LOCA Core Damage Frequency Based on Thermal-Hydraulics Analysis”. Nuclear Engineering and Design, Volume (315), 2017, pp. 77-92.

[8]. A. Loghman, M. Moradi. "Creep Damage and Life Assessment of Thick-Walled Spherical Reactor Using Larson-Miller Parameter". International Journal of Pressure Vessel and Piping, Volume (151), 2017, pp. 11-19.

[9]. C.H. Chang, H.W. Chou, C.C. Huang. "Development and Application of Safety Assessment System in PFM Analysis for RPV to Study the Influence of the Neutron Fluence Estimate". International Journal of Pressure Vessel and Piping, Volume (167), 2018, pp. $43-51$.

[10]. Y. Mei, Y. Shao, S. Gong, Y. Zhu, H. Gu. "Effects of Surface Orientation and Heater Material on Heat Transfer Coefficient and Critical Heat Flux of Nucleate Boiling". International Journal of Heat and Mass, Volume (121), 2018, pp. 632-640.

[11]. E.V. Dontsov, F. Zhang. "Calibration of Tensile Strength to Model Fracture Toughness with Distinct Element Method". International Journal of Solids and Structures, Volume (144-145), 2018, pp.180191.
[12]. Dai, H.L., Luo, W.F., Dai, T.2016. Multi-Field Coupling Static Bending of a Finite Length Inhomogeneous Double-Layered Structure with Inner Hollow Cylinder and Outer Shell. Applied Mathematical Modelling:40, 6006-6025.

[13]. J.F. Mao, J.W. Zhu, S.Y. Bao, L.J. Luo, Z.L. Gao. “ Study on Structural Failure of RPV with Geometric Discontinuity under Severe Accident". Nuclear Engineering and Design, Volume (307), 2016, pp. 354-353.

[14]. J.W. Hutchinson, J.M.T. Thompson. "Imperfections and Energy Barriers in Shell Buckling". International Journal of Solids and Structures, Volume (148-149), 2018, pp. 157-168.

[15]. M. Nistor, R. Wiebe, I. Stanciulescu. "Relationship Between Euler Buckling and Unstable Equilibria of Buckled Beams". International Journal of NonLinear Mechanics, Volume (95), 2017, pp. 151-161. 